\title{
Charakterystyka somatyczna oraz stan odżywienia polskich kobiet stuletnich
}

\section{Characteristics of the somatic and nutritional status of polish centenarian women}

\author{
Romana Pawlińska-Chmara \\ Samodzielna Katedra Biotechnologii i Biologii Molekularnej Uniwersytetu Opolskiego \\ ul. Kardynała Kominka 6-6a, 45-032 Opole \\ Kierownik: prof. dr hab. Adam Latała
}

\begin{abstract}
SUMMARY
Introduction: The aim of the study was to carry out the first analysis in Poland of Polish centenarian women to identify their somatic and nutritional status.

Material and methods: Research was carried out within the framework of the PolStu 2001 project implemented in 20012005 , while other studies were conducted in $2005-2007$ by the author of this paper. The study comprised 361 women aged 100 years. The characteristics of the nutritional status of women were established on the basis of anthropometric measurements. Data were analyzed with Statistica 8 software. The level of significance for all analyses was $\mathrm{p}<0.05$.
\end{abstract}

Results: Studies have shown that Polish centenarian women are characterised by a specific physique and android obesity. Conclusions: The analysis carried out can provide a platform for further fundamental research that can explore aging, and in addition to the scientific value can be helpful in creating social programmes that are targeted at the population of long-lived people, and of the administrative structure of the country developed at different levels. Such programmes can serve to ensure the quality of life of long-lived seniors.

Key words: 100 -year-old women, somatic structures, nutritional status.

\section{STRESZCZENIE}

Wstęp: Celem pracy było przeprowadzenie po raz pierwszy w historii polskich kobiet charakterystyki somatycznej stulatek oraz ocena stanu ich odżywienia.

Materiał i metody: Część badań wykonano w ramach projektu PolStu 2001 realizowanego w latach 2001-2005, a pozostałe wykonane zostały w latach 2005-2007 przez autorkę prezentowanego opracowania. Wielkość próby wynosiła 361 przebadanych kobiet stuletnich. Charakterystykę stanu odżywienia badanych kobiet określono na podstawie pomiarów antropometrycznych. Uzyskane dane poddano analizie statystycznej za pomocą pakietu Statistica 8. Jako poziom istotności statystycznej dla wszystkich analiz przyjęto wartość $\mathrm{p}<0,05$.
Wyniki: Polskie kobiety stuletnie cechuje określona budowa ciała oraz androidalny typ otłuszczenia.

Wnioski: Przeprowadzona analiza może stanowić platformę dla dalszych badań podstawowych zgłębiających proces starzenia się człowieka, ale oprócz walorów poznawczych może być pomocna w tworzeniu programów społecznych uwzględniających kohortę ludzi długowiecznych na różnych poziomach struktury administracyjnej kraju. Programy takie służą zapewnieniu jakości wydłużonego życia.

Słowa kluczowe: polskie kobiety stuletnie, budowa somatyczna, stan odżywiania.

\section{WSTĘP}

Starość jest etapem ontogenezy, który kończy rozwój. Starzenie się jest procesem fizjologicznym przebiegającym bezwarunkowo. Kaczmarek i Szwed [1] w starzeniu się widzą sukcesywnie następujące strukturalne oraz funkcjonalne zmiany rozwojowe, które określają stopień wyczerpania się możliwości biologicznych organizmu. Każdy organizm, będący w tym samym wieku kalendarzowym, ma różny stopień rozwoju biologicznego. W auksologii najczęściej stosowane są następujące wyznaczniki wieku biologicznego: wiek szkieletowy, wiek zębowy, wiek drugorzędnych cech płciowych, wiek morfologiczny i wiek sprawności fizycznej. Metody te są stosowane w fazie progresywnej, natomiast tracą przydatność $\mathrm{w}$ fazie stabilnej i inwolucyjnej $[1,2]$. W gerontologii wykorzystuje się kryteria oparte na wielocechowej metodzie testów, podstawę których stanowią pomiary antropometryczne [2]. Konsekwencją postępujących zmian inwolucyjnych jest m.in. wykonywanie czynności związanych z samoobsługą, w tym przygotowywanie posiłków. Trudności w żuciu pokarmów mogą także przyczynić się do niewłaściwego sposobu żywienia, a w następstwie do obniżenia sprawności psychofizycznej kobiet stuletnich.

Celem pracy było przede wszystkim przeprowadzenie po raz pierwszy w historii polskich kobiet charakterystyki somatycznej stulatek oraz ocena stanu ich odżywienia. 


\section{MATERIA $~ I$ METODY}

Badaniami objęto kobiety stuletnie mieszkające na terenie województw: małopolskiego, mazowieckiego, opolskiego, śląskiego, podkarpackiego i świętokrzyskiego. Część badań została wykonana w ramach projektu PolStu 2001 „Genetyczne i środowiskowe czynniki długowieczności populacji polskiej” realizowanego w latach 2001-2005, natomiast pozostałe wykonane zostały w latach 2005-2007 przez autorkę prezentowanego opracowania. Informacje o kobietach długowiecznych uzyskiwano w odpowiednich urzędach gminy lub miasta. Docierano do kobiet także dzięki informacji uzyskanej w parafiach miast i wsi. Badaniami objęto kobiety stuletnie urodzone latach 1898-1905. Mianem „stulatki” określono każdą kobietę, która w chwili badania miała ukończone 100 lat (obchodziła setną rocznicę urodzin). Wielkość próby to 361 przebadanych kobiet stuletnich. Badana grupa jest unikalna, nie stanowi jednak grupy reprezentującej populację wszystkich polskich kobiet długowiecznych. Z przyczyn etycznych nie wykonano badań w przypadku, gdy kobieta była w bardzo złym stanie zdrowia. Nie uwzględniono także danych niekompletnych pochodzących głównie od kobiet, u których występowały poważne problemy ze zdrowiem fizycznym i psychicznym. Udział w programie badawczym PolStu 2001 umożliwił opracowanie somatometrii, dla której autorka została zaangażowana jako wykonawca tej części projektu. Jednocześnie upoważniono ją do wykorzystania i opracowania udostępnionych nielicznych danych dotyczących charakterystyk społeczno-kulturowych. Dotychczasowe wyniki badań wg programu PolStu 2001 publikowane są cząstkowo [3]. Charakterystykę stanu odżywienia badanych kobiet określono na podstawie pomiarów wybranych cech antropometrycznych: wysokości i masy ciała oraz obwodu talii i obwodu bioder.

Zgodność rozkładów empirycznych analizowanych zmiennych z rozkładem normalnym oceniono za pomocą testu Shapiro-Wilka. Istotność różnic pomiędzy grupami oceniano za pomocą jednoczynnikowej analizy wariancji. Dane procentowe porównano za pomocą testu $\chi^{2}$. W ocenie istotności efektów przyjęto poziom $\mathrm{p}<0,05$. Obliczeń dokonano, wykorzystując pakiet programów statystycznych Statistica 8.0.

\section{WYNIKI I DYSKUSJA}

Średnia wieku zbadanych kobiet w ramach projektu PolStu 2001 wynosiła 101,1 lat [4], natomiast dla całości grupy w ramach własnego projektu badawczego (dane z projektu oraz badań własnych) wyniosła 101,6 lat (tab. 1, ryc. 1).

\section{Cechy społeczno-kulturowe polskich kobiet stuletnich}

W tabeli 2 przedstawiono społeczno-demograficzną charakterystykę polskich kobiet stuletnich.

\section{Miejsce zamieszkania}

Na podstawie danych ze spisów powszechnych należy oczekiwać, iż sędziwe kobiety w przeważającej większości będą
TABELA 1. Wiek badanych kobiet (dane własne)

\begin{tabular}{cccccc}
$\mathbf{n}$ & $\mathbf{M}$ & Mediana & Minimum & Maksimum & SD \\
\hline 361 & 101,6 & 101,2 & 100,01 & 111,8 & 1,8 \\
\hline
\end{tabular}

n - liczba badanych; M - wiek; SD - odchylenie standardowe

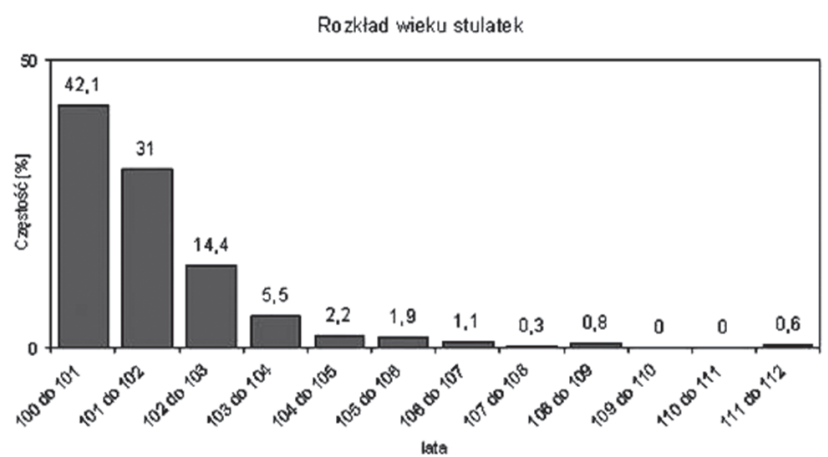

RYCINA 1. Rozkład wieku badanych kobiet (dane własne)

TABELA 2. Społeczno-demograficzna charakterystyka polskich kobiet stuletnich (dane własne)

\begin{tabular}{lcc} 
& Kobiety & $\%$ \\
\hline Liczba badanych & 361 & 100 \\
\hline Wiek (średnia) & 101,6 & \\
\hline Miejsce zamieszkania & & 65 \\
\hline Miasto & 235 & 35
\end{tabular}

\begin{tabular}{lcc}
\hline Stan cywilny & & \\
\hline Wolna & 18 & 4,9 \\
\hline Wdowa & 341 & 94,5 \\
\hline Rozwiedziona & 2 & 0,6 \\
\hline Wykształcenie & & \\
\hline Analfabeta & 40 & 11,1 \\
\hline Samouk & 43 & 11,9 \\
\hline Podstawowe & 191 & 52,9 \\
\hline Średnie & 65 & 18,0 \\
\hline Niepełne wyższe & 8 & 2,2 \\
\hline Wyższe & 14 & 3,9
\end{tabular}

\begin{tabular}{lcc}
\hline Zamieszkanie & 35 & \\
\hline Sama & 226 & 9,7 \\
\hline Z dziećmi & 29 & 62,6 \\
\hline Dom Opieki & 4 & 1,1 \\
\hline Rodzeństwo & 51 & 14,2 \\
\hline Z innymi krewnymi & 16 & 4,4 \\
\hline Z przyjaciółmi & 51 & \\
\hline Sytuacja ekonomiczna & 182 & 14,1 \\
\hline Bardzo dobra & 99 & 50,4 \\
\hline Dobra & 29 & 27,4 \\
\hline Średnia & & 8,1 \\
\hline Zła i bardzo zła & 345 & 4,4 \\
\hline Stosunek do religii & 16 &
\end{tabular}


mieszkankami wsi, bowiem są to jednostki, których wybór odnośnie do miejsc zamieszkania dokonany został kilkadziesiąt lat temu, a zatem odpowiada wzorcom obowiązującym kilka dekad wcześniej [5]. Jednakże wyniki badań własnych wskazują na fakt, że duży odsetek (65) badanych kobiet stanowią mieszkanki miast (tab. 2). Wyjaśnienia tego faktu należały szukać przede wszystkim w obowiązujących w Polsce wzorcach opieki nad starcami, zgodnie z którymi obowiązek ten spada głównie na dzieci [6]. W przypadku, gdy dzieci opuściły obszar wiejski, gdzie się urodziły i wychowały, i przeniosły się do miast, oznacza to również zmianę miejsc zamieszkania osoby starszej.

\section{Stan cywilny}

Ważną cechą opisującą osoby bardzo stare jest ich stan cywilny, ponieważ osoby długowieczne to grupa, która w znacznym stopniu potrzebuje pomocy w rozwiązywaniu licznych problemów dnia codziennego. Zdecydowana większość kobiet w przeszłości założyła rodzinę, dlatego też wyniki badań wskazują na duży odsetek wdów $(94,5)$. Wdowieństwo nie stanowi jednakże jedynej przyczyny osamotnienia cywilnego. Innymi powodami tego stanu jest bezżeństwo i rozwód (5,5\%). Nie było żadnej stulatki, która w chwili badania pozostawała w związku małżeńskim.

\section{Wyksztatcenie}

Poziom wykształcenia kobiet stuletnich stanowi w pewnym sensie stygmat czasów ich młodości. Z drugiej strony wykształcenie jest często traktowane jako jednocześnie marker statusu społecznego. Uzyskano wyniki wskazujące, że najstarsze kobiety polskie stanowią subpopulację osób o dużym odsetku wykształcenia co najmniej podstawowego.

\section{Zamieszkanie}

Nieliczne kobiety długowieczne $(9,7 \%)$ zamieszkują samotnie, natomiast zdecydowana większość mieszka ze swoimi dziećmi. Uwagę zwraca niewielki odsetek badanych umieszczonych w domach opieki $(8,0)$, co odróżnia Polskę od innych krajów rozwiniętych, w których znacznie więcej osób stuletnich pozostaje w ośrodkach leczniczo-opiekuńczych [7, 8, 9]. Wydaje się, że ten niski odsetek nie wynika tylko ze słabego rozwoju bazy leczniczo-opiekuńczej, która w ostatnich latach znacznie się poprawiła, ale jest związany przede wszystkim z zachowaniem silnych więzi rodzinnych. Potwierdzają to także badania włoskie, gdzie w niektórych regionach w zakładach opiekuńczych żyje co dziesiąty stulatek [7].

\section{Sytuacja materialna}

Pośród badanych ponad 60\% kobiet zadeklarowało swoją obecną sytuację materialną jako bardzo dobrą oraz dobrą.

\section{Stosunek do religii}

Dyczewski [10] w swoich badaniach osób starszych potwierdził zależność między wiekiem a religijnością. Stwierdził, że wraz z wiekiem wzrasta lęk przed chorobą kojarzoną często ze stanem bezradności i uzależnienia od innych ludzi. Wzrasta też lęk przed śmiercią i samotnością. Wraz z procesem starzenia rozwijają się bowiem u ludzi wewnętrzne formy wyciszenia. Większość pozostaje także we wzorach religijności wcześniejszych okresów swojego życia. Jest to na ogół postawa bardzo osobista.

\section{Pomiary somatyczne polskich kobiet stuletnich}

Pomiary somatyczne po odpowiednich przeliczeniach, dostarczają informacji o głównych składnikach całego ciała [11, 12, 13]. Dane te mogą być pomocne m.in. przy określaniu niedowagi, a także nadwagi i otyłości, często spotykanych u ludzi starszych, u których obserwuje się ograniczenie aktywności ruchowej przy niezmienionej wielkości spożycia pokarmów. Zarówno niedowaga, jak i nadwaga lub otyłość są dodatnio skorelowane ze współczynnikami zachorowalności oraz śmiertelności [14].

Najczęściej przedmiotem badań antropologicznych była wysokość ciała, pod względem której proces inwolucji organizmu zarówno u mężczyzn, jak i u kobiet być może daje się uchwycić najlepiej $[15,16]$. W badaniach zwracano uwagę także na zmiany starcze w innych cechach antropometrycznych. Klimek i Skrzat [17] oraz Broczek i wsp. [18] wykazali, że u kobiet w wieku 31-80 lat oraz w populacji osób stuletnich, oprócz zmian wysokości ciała następuje zmiana kształtu klatki piersiowej w kierunku beczkowatej, rozedmowej, poprzez zwiększanie się jej wymiaru strzałkowego, a tym samym i wskaźnika klatki piersiowej. Kudelski [19] oraz Pawlińska-Chmara [20] opisali dokładnie, jak w wyniku starzenia się układu ruchu wytwarza się m.in. postawa starcza (garbienie się). W ostatnich latach światowe piśmiennictwo zawiera nieliczne pozycje informujące o obserwacjach nad zmianami morfologicznymi i fizjologicznymi osób długowiecznych [21, 22], jednakże dotychczas brak było danych antropometrycznych o populacjach polskich kobiet stuletnich.

Celem pogłębienia i rozszerzenia wiedzy dotyczącej zmian inwolucyjnych w tak późnym wieku dokonano opracowania wybranych cech antropometrycznych polskich kobiet stuletnich, które zachowały przynajmniej minimalną sprawność w samoobsłudze (tab. 3).

Według deklaracji zbadanych stulatek od 50. r.ż. ich wysokość ciała zmniejszyła się średnio o 6,3 cm, a masa ciała spadła średnio o $17,9 \mathrm{~kg}$.

TABELA 3. Charakterystyka somatyczna polskich kobiet stuletnich badania obecne i dane retrospektywne (dane własne)

\begin{tabular}{lccc}
\multicolumn{1}{c}{ Zmienna } & $\mathrm{n} / \mathrm{N}$ & $\mathbf{M}$ & SD \\
\hline Wysokość ciała w wieku 100 lat (cm) & 361 & 148,0 & 7,1 \\
\hline Wysokość ciała w wieku 50 lat (cm) & $\begin{array}{c}304 \\
(361)\end{array}$ & 154,3 & 3,9 \\
\hline Masa ciała w wieku 100 lat (kg) & 361 & 48,4 & 9,1 \\
\hline Masa ciała w wieku 50 lat (kg) & $\begin{array}{c}314 \\
(361)\end{array}$ & 66,3 & 9,6 \\
\hline BMI w wieku 100 lat (kg/m²) & 361 & 22,1 & 3,8 \\
\hline $\begin{array}{l}\text { BMI w wieku 50 lat (kg/m²) } \\
\text { Ubytek wysokości ciała w stosunku }\end{array}$ & $\begin{array}{c}304 \\
\text { do wartości w 50. r.ż. }\end{array}$ & 26,3 & 4,0 \\
\hline $\begin{array}{l}\text { Ubytek masy ciała w stosunku } \\
\text { do wartości w 50. r.ż. }\end{array}$ & 314 & 10,3 & 6,1 \\
\hline
\end{tabular}

n - liczba danych; M - wiek; SD - odchylenie standardowe 
Postępujący z wiekiem ubytek wysokości ciała może być wynikiem zmian krzywizn kręgosłupa, w tym części lędźwiowej, prowadzących do zbliżania się łuków żebrowych do kolców górnych talerza biodrowego z przemieszczaniem się zawartości jamy brzusznej do przodu i boków kosztem powiększania się talii, zmniejszenia grubości chrząstek międzykręgowych oraz stawowych, a także rezultatów osteoporozy [23, 24]. Według Chumlea i wsp. [25] obserwowana utrata wysokości ciała pomiędzy 60. a 80. r.ż. wynosi ok. 0,5 cm/rok.

Celem określenia ewentualnych tendencji zmian wymiarów ciała z wiekiem badanych 100.-111. r.ż. obliczono odpowiednie współczynniki korelacji uporządkowania (rang) Spearmana. Wszystkie okazały się być ujemne. W większości pomiarów somatycznych nie wykazano istotnie statystycznego kierunku zmian. Jedynie z wiekiem badane kobiety stuletnie szczupleją w talii (tab. 4). Po przekroczeniu setnego roku życia konstytucja somatyczna kobiet nie ulega już dużym zmianom, jednakże w analizowanym materiale kierunek zmian jest taki sam jak między 50. a 100. r.ż.: wysokość i jego masa nadal maleje.

TABELA 4. Korelacja rang Spearmana analizowanych cech somatycznych kobiet w wieku 100-111 lat $z$ ich wiekiem (dane wtasne)

\begin{tabular}{lll}
\multicolumn{1}{c}{ Zmienna } & $\mathbf{n}$ & \multicolumn{1}{c}{$\mathbf{R}$} \\
\hline Wysokość ciała $(\mathrm{cm})$ & 361 & $-0,02(\mathrm{NS})$ \\
\hline Masa ciała $(\mathrm{kg})$ & 361 & $-0,02(\mathrm{NS})$ \\
\hline BMI $\left(\mathrm{kg} / \mathrm{m}^{2}\right)$ & 361 & $-0,02(\mathrm{NS})$ \\
\hline Obwód w talii $(\mathrm{cm})$ & 361 & $-0,11(\mathrm{p}=0,04)$ \\
\hline Obwód w biodrach $(\mathrm{cm})$ & 361 & $-0,01(\mathrm{NS})$ \\
\hline WHR & 361 & $-0,10(\mathrm{p}=0,05)$ \\
\hline
\end{tabular}

n - liczba badanych; R - współczynnik korelacji rang Spearmana

Istotnymi komponentami masy ciała jest masa mięśni i otłuszczenie. Starzenie przynajmniej w początkowym okresie kojarzone jest często ze wzrostem komponenty tłuszczu. Ubytek masy ciała w podeszłym wieku świadczyć może przede wszystkim o spadku masy mięśni, a to w konsekwencji i siły [21]. U starszych ludzi brak aktywności fizycznej może sam w sobie być przyczyną atrofii mięśniowej [26]. Również słabe przyswajanie dietetyczne może być powodem utraty protein mięśniowych [27].

\section{Kobiety stuletnie na tle kobiet z I zdjęcia antropometryczego Polski}

Analizę wysokości i masy ciała stuletnich kobiet w wieku 50 lat porównano do danych wysokości i masy ciała kobiet z I zdjęcia antropometrycznego Polski (tab. 5).

Wysokość ciała jest cechą ekosensytywną, a prace wskazują na jej korelacje ze statusem społeczno-ekonomicznym [28, 29]. Prezentowane wyniki analizy wysokości ciała kobiet wskazują na istotnie statystyczny niższy wzrost badanych kobiet stuletnich w ich 50. r.ż. w porównaniu do danych z I zdjęcia antropometrycznego Polski [30]. Prawdopodobnie niższy wzrost kobiet stuletnich jest wynikiem statusu społeczno-ekonomicznego. Większość z nich w latach młodości wychowała się i pracowała na wsi.
TABELA 5. Analiza wysokości ciała i masy ciała kobiet

\begin{tabular}{|c|c|c|c|c|}
\hline Zmienna & $n$ & $M$ & SD & $\begin{array}{c}\text { Test } \\
\text { t-Studenta }\end{array}$ \\
\hline $\begin{array}{l}\text { Wysokość ciała kobiet } \\
\text { stuletnich w wieku } 50 \text { lat } \\
\text { (dane retrospektywne) }\end{array}$ & 304 & 154,3 & 3,9 & \multirow[b]{2}{*}{$p=0,0001$} \\
\hline $\begin{array}{l}\text { Wysokość ciała kobiet } \\
\text { wg danych z I zdjęcia } \\
\text { antropometrycznego Polski } \\
\text { (1955-1956) wg Górnego, } 1972 \text { r. }\end{array}$ & 14052 & 155,6 & 5,5 & \\
\hline $\begin{array}{l}\text { Masa ciała kobiet stuletnich } \\
\text { w wieku } 50 \text { lat } \\
\text { (dane retrospektywne) }\end{array}$ & 314 & 66,3 & 9,6 & \multirow[b]{2}{*}{$p<0,000001$} \\
\hline $\begin{array}{l}\text { Masa ciała kobiet wg danych } \\
\text { z I zdjęcia antropometrycznego } \\
\text { Polski (1955-1956) } \\
\text { wg Górnego, 1972 r. }\end{array}$ & 11650 & 57,4 & 8,8 & \\
\hline
\end{tabular}

Samaras i wsp. [31] wykazali w swoich badaniach, że właśnie niski wzrost ludzi może być uznany jako predyktor dłuższego życia. Wyniki najnowszych badań amerykańskich naukowców potwierdzają fakt, że osoby niskiego wzrostu rzeczywiście mają większa szansę na długowieczność [32].

Wyniki analizy masy ciała kobiet wskazują jedynie na istotnie statystycznie wyższą masę badanych kobiet stuletnich w ich 50. r.ż. w porównaniu do danych z I zdjęcia antropometrycznego Polski [30] (tab. 5).

\section{Stan odżywienia polskich stulatek}

Stan odżywienia kobiet stuletnich oceniono na podstawie pomiarów antropometrycznych, za pomocą wskaźnika masy ciała (BMI) i współczynnika proporcji obwodów talia/biodra (WHR). Wprawdzie wyniki tych pomiarów nie odzwierciedlają dokładnie stanu rzeczywistego [33], tym niemniej są wskaźnikami dotychczas powszechnie stosowanymi w ocenie stanu odżywienia osób starszych otrzymywanymi prostymi i tanimi metodami [34].

Średnie wartości wskaźnika BMI kobiet stuletnich mieściły się w granicach wartości uznawanych za prawidłowe. Prawidłowy stan odżywienia stwierdzono u 250 (69,3\%) badanych, niedowagę (BMI $\left.<18,5 \mathrm{~kg} / \mathrm{m}^{2}\right)-\mathrm{u} 47(14,1 \%)$, natomiast nadwagę lub otyłość (BMI > 25,0 kg/m²) - u 60 (26,6\%).

Stulatki deklarowały znacznie większą niż w chwili badania masę ciała w wieku 50 lat, a co za tym idzie charakteryzowały się w tedy częściej dużymi wartościami wskaźnika BMI (tab. 3). Zwiększanie masy ciała we wczesnym okresie pomenopauzalnym tłumaczone jest zmianami metabolicznymi związanymi z wygaśnięciem czynności jajników, a często także zmniejszeniem aktywności fizycznej związanej z zakończeniem pracy zawodowej [35, 36]. Akahosi i wsp. [37] wykazali, że wyższe wartości wskaźnika BMI posiadały kobiety, które później przechodziły menopauzę. Otłuszczenie wg nich chroni więc przed wczesną menopauzą.

Ważna jest też lokalizacja odkładania tłuszczu. Prostym sposobem oceny typu otyłości jest współczynnik WHR. Według danych z piśmiennictwa proporcja obwodów talia/biodra wiąże się silnie z wiekiem, płcią i wartością wskaźnika BMI [38]. 
Kirchengast [39] w trakcie badań zaobserwowała, że bardziej korpulentne kobiety z wyższymi wartościami obwodów pasa i bioder produkują więcej estrogenów w okresie klimakterium w porównaniu z bardzo szczupłymi kobietami. Dzięki temu nasilenie objawów wypadowych u tych kobiet jest istotnie niższe niż wśród szczupłych rówieśniczek.

Wyniki badań wskazują też, że wzrost masy tłuszczowej wywiera większy wpływ na profil metaboliczny u starzejących się kobiet niż masa ciała per se. Przyrost tkanki tłuszczowej, prowadzący do otyłości wisceralnej (otyłości androidalnej), zwiększa ryzyko wystąpienia zaburzeń metabolicznych (gospodarki tłuszczowej i węglowodanowej) będących przyczyną chorób takich, jak: nadciśnienie tętnicze, miażdżyca czy cukrzyca typu II [40]. Warto odnotować, że miara obwodu talii u bardzo starych osób może wiązać się nie tylko z otłuszczeniem wisceralnym, lecz także z ilością zgromadzonych w jamie brzusznej gazów $[41,42]$.

Współczynnik WHR jest ważną miarą antropometryczną pozwalającą rozróżnić typy otyłości jako: otyłość androidalną (zwaną również otyłością wisceralną) - gdy nadmiar tkanki tłuszczowej występuje w okolicach jamy brzusznej, oraz gynoidalną - gdy nadmiar otłuszczenia zlokalizowany jest w okolicach bioder i pośladków. Otyłość androidalna (tzw. jabłko) występuje głównie u mężczyzn. Notowana jest również u kobiet po menopauzie, a także w rezultacie skłonności dziedzicznej. Otyłość gynoidalna (tzw. gruszka) występuje głównie u kobiet przed i w okresie klimakterium jako typowa cecha silnie związana z dymorfizmem płciowym. Większość badanych kobiet stuletnich reprezentowała otyłość androidalną. Średnia wartość wskaźnika WHR w grupie badanych stulatek przekroczyła wartość graniczną 0,8, co wskazuje na duże nagromadzenie u większości badanych tkanki tłuszczowej w okolicach jamy brzusznej (ryc. 2).

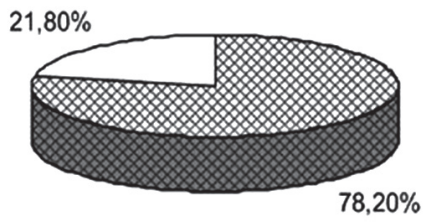

๑ Otyłość androidalna ๑Otyłość gynoidalna

RYCINA 2. Rozkład wskaźnika WHR badanych kobiet (kategorie: $<0,8$ - typ otyłości gynoidalnej, tzw. gruszka, oraz >0,8 - otyłość androidalna, tzw. jabłko) (WHO 1995, dane własne)

Według danych z piśmiennictwa, wzrost trzewnego depozytu tkanki tłuszczowej wiąże się u kobiet z podwyższonym poziomem insulinopodobnego czynnika wzrostu IGF-1, a także wzmożenia wydzielania kortyzolu oraz ze wzrostem stężenia testosteronu. Baranowska i wsp. [43] wykazały, że stężenie kortyzolu u 75 badanych przez nie kobiet stuletnich było wyższe w porównaniu z grupą kobiet w wieku poniżej 50 lat. Obserwowane przez badaczki zmiany w wydzielaniu neuropeptydu Y (NPY) i leptyny mogą również modulować wydzielanie kortyzolu, co wykazała dodatnia korelacja między NPY i kortyzolem ( $r=0,29$; $p<0,05)$.

\section{PODSUMOWANIE I WNIOSKI}

Na podstawie wyników badań stwierdzono, że polskie kobiety stuletnie cechuje określona budowa ciała (wysokość i masa ciała) oraz androidalny typ otłuszczenia. Posługiwanie się przy ocenie stanu odżywienia osób stuletnich wskaźnikami BMI i WHR, przeznaczonymi dla osób młodszych, budzić może wątpliwości interpretacyjne związane z faktem, że wraz z wiekiem następują zmiany składu i budowy ciała, które należałoby odnosić do zmodyfikowanych wskaźników, odpowiednio je uwzględniając.

Przeprowadzona analiza może stanowić zaczyn dla dalszych badań podstawowych zgłębiających proces starzenia się człowieka, ale oprócz walorów poznawczych może być pomocna w tworzeniu programów społecznych uwzględniających kohortę ludzi długowiecznych na różnych poziomach struktury administracyjnej kraju. Programy takie służą zapewnieniu odpowiedniej jakości wydłużonego życia.

\section{PIŚMIENNICTWO}

1. Kaczmarek M., Szwed A.: Koncepcja wieku biologicznego w różnych fazach ontogenezy człowieka. Now Lek. 1988, 67, 855-864.

2. Hofecker G., Niedermüller H., Skalicky M.: Assessment of modification of the rate of aging. Arch Gerontol Geriatr. 1991, 12 (2-3), 273-276.

3. Mossakowska M.: Program badania polskich stulatków “PolStu 2001”. In: Skazani na długowieczność. W poszukiwaniu czynników pomyślnego starzenia. Eds: M. Mossakowska, K. Broczek, M. Witt. Ośrodek Wydawnictw Naukowych, Poznań 2007, 9-11.

4. Mossakowska M., Jaczewska B.: Ile lat ma polski stulatek? In: Starość i starzenie jednostek i zbiorowości ludzkich. Eds: T. Kowaleski, P. Szukalski. Zakład Demografii Uniwersytet Łódzkiego, Łódź 2006, 351-354.

5. Rocznik Statystyczny GUS, 1999.

6. Pędich $W$ : Specyfika badań środowiskowych populacji ludzi bardzo starych: niehomogenność wieku i środowiska. In: Reformy społeczne i zagrożenia ich realizacji. Eds: L. Frąckiewicz, W. Koczuła. Wyd. AE, Katowice 1988.

7. Gueresi P., Troiano L., Minicuci N., Bonafe M., Pini G., Salvioli G et al.: The MALVA (M Antova Longe VA) study an investigation on people 98 years of age and over in on province of Northern Italy. Exp Gerontol. 2003, 38 (10), 1189-1197.

8. Krach C.A., Velkoff V.A.: Centenarians in the United States, 1990, U.S Department of Commerce, Economics and Statistics, 1999.

9. Samuelsson S.M., Alfredson B.B., Hagberg B., Samuelsson G., Nordbeck B., Brun A. et al:: The Swedish Centenarian Study: a multidisciplinary study of five consecutive cohorts at the age of 100. Int J Aging Hum Dev. 1997, 45 (3), 223-253.

10. Dyczewski L.: Ludzie starzy i starość w społeczeństwie i kulturze. RW KUL, Lublin 1994, 100-103.

11. Roszkowski W., Pawlińska-Chmara R.: Somatometria osób starszych jako wskaźnik stanu odżywienia. Rocz Państ Zakł Hig. 2003, 54, (4), 399-408.

12. Charzewska J.: Ocena stanu odżywienia. In: Żywienie człowieka. Podstawy nauki o żywieniu. Eds: J. Gawęcki, L. Hryniewiecki. PWN, Warszawa 1998, 481-494

13. Deurenberg P., van der Kooy K., Hulshof T., Evers P.: Body mass index as a measure of body fatness in the elderly, Eur J Clin Nutr. 1989, 43 (4), 231-236.

14. Deeg D.J., Miles T.P., van Zonneveld R.J., Carb J.D.: Weight change, survival time and cause of death in Dutch elderly. Arch Gerontol Geriatr 1990, 10 (1), 97-111.

15. Klaus E.: Zmienność cech antropologicznych w procesie starzenia się. Acta Univ Wrat. Prace Zoologiczne. 1974, 5, 77-118. 
16. Panek S.: Zmiany sekularne a procesy inwolucyjne wysokości ciała (na przykładzie ludności wsi Lutcza w woj. rzeszowskim). Mat Prace Antr. 1978, 95, 23-42.

17. Klimek W., Skrzat J.: Analiza somatotypu kobiet krakowskich, Zeszyty Naukowe Uniwersytetu Jagiellońskiego. Prace Zool. 1995, 41, 199-205.

18. Broczek K., Pawlińska-Chmara R., Kupisz-Urbańska M., Mossakowska M. Anthropometric chest structure of Polish centenarians. J Physiol Pharmacol. 2005, 56, Suppl. 4, 9-13.

19. Kudelski W.: Zmiany wysokości ciała w procesie starzenia się mężczyzn. Mat Prace Antr. 1983, 104, 35-46.

20. Pawlińska-Chmara R.: Ocena porównawcza ogólnego stanu zdrowia budowy ciała i wydolności układu oddechowego pracowników dwóch zakładów w województwie śląskim i opolskim. Acta Univ Wrat Studia Antropologiczne. 2001, 6, 67-93.

21. Paolisso G., Gambardella A., Balbi V., Ammendola S., D'Amore A., Varricchio M.: Body composition, body fat distribution, and resting metabolic rate in healthy centenarians. Am J Clin Nutr. 1995, 62 (4), 746-750.

22. Stathakos D., Pratsinis H., Zachos I., Vlahaki I., Gianakopoulu A., Zianni D. et al.: Greek centenarians: assessment of functional health status and life-style characteristics. Exp Gerontol. 2005, 40 (6), 512-518.

23. Chabros E., Charzewska J., Rogalska-Niedźwiedź M., Wajszczyk B., Lachowicz A., Ziemiański S.: Zmiany wskaźników antropometrycznych stanu odżywienia osób w podeszłym wieku z Warszawy w czasie 5 lat. Żyw Człow Metab. 1998, 25 (1), 1-3.

24. Sowers M.F.: Osteoporosis and osteomalacia. In: Present Knowledge in Nutrition. International Life Sciences. Institute Nutrition Foundation, Washington 1990.

25. Chumlea W.C., Garry P.J., Hunt W.C., Rhyne R.L.: Distributions of serial changes in stature and weight in a healthy elderly population. Hum Biol. 1988, 60 (6), 917-923.

26. Fiatarone M.A., Marks E.C., Ryan N.D., Meredith C.N., Lipsitz L.A., Evans W.J.: High-intensity strength training in nonagenarians. Effects on skeletal muscle. JAMA. 1990, 263 (22), 3029-3034.

27. Falciglia G., O'Connor J., Gedling E.: Upper arm anthropometric norms in elderly while subjects. J Am Diet Assoc. 1988, 88 (5), 569-574.

28. Skrzypczak M., Szwed A., Pawlińska-Chmara R., Skrzypulec V.: Associations of Body Mass Index, Waist Circumference, Waist-to-Hip Ratio, and Waist-to-Height Ratio with menopausal status, socio-demographic, and life style factors in Polish women. In: Ageing related problems in past and present populations. Biennial Book of EAA, 2008. Vol. 5. Plantin Publ. \& Press Ltd, Budapest 2008, 143-158.

29. Bielicki T., Malina R., Waliszko A.: Monitoring of the dynamics of social stratification: stature variation among Polish conscripts in 1976 and 1986. Am J Hum Biol. 1992, 4, 345-350.

30. Górny S.: Zdjęcie antropometryczne Polski, część I. Pomiary ludności dorosłej z lat 1955-1956. Mat Prace Antr. 1972, 84

31. Samaras T.T., Elrick H., Storms L.H.: Is height related to longevity? Life Sci. 2003, 72 (16), 1781-1802.

32. Suh Y., Atzmon G., Cho M.O., Hwang D., Liu B., Leahy D.J. et al.: Functionally significant insulin-like growth factor I receptor mutations in centenarians. Proc Natl Acad Sci USA. 2008, 105 (9), 3438-3442.

33. WHO Expert Committee. 1995. Physical status; the use and interpretation of anthropometry. Technical Report Series, nr 854, Geneva World Health Organization.

34. Jensen E., Dehlin O., Hagberg B., Samuelsson G., Svensson T.: Body mass index in relation to medical, psychological and sociological factors in an 80 year old population. In: Nutrition intervention and the elderly. Eds: B.J. Vellas, P. Sachet, R.J. Baumgartner. Facts Res Gerontol 1995, 143-156.

35. Deurenberg P.: Anthropometry (Instructions for fieldworker). In: Nutrition and the elderly. Manual of operation. Eds: C.P.G.M. de Groot, W. van Straveren. EURO-NUT report 11, Wageningen 1988.

36. Deurenberg P., van der Kooy K., Hulshof T., Evers P.: Body mass index as a measure of body fatness in the elderly. Eur J Clin Nutr. 1989, 43 (4), 231-236.

37. Akahosi M., Soda E., Nakashima T., Tominaga S., Ichimaru S., Seto S. et al.: The effects of body mass index on age at menopause. Int J Obes Relat Metab Disord. 2002, 26 (7), 961-968.

38. Jakicic J.M., Donnelly J.E., Jaward A.F., Jacobsen D.J., Gunderson S.C., Pascale R. Association between blood lipids and different measures of body fat distribution: effect of BMI and age. Int J Obes. 1993, 17 (3), 131-137.
39. Kirchengast S.: Anthropometric-hormonal correlation patterns in fertile and postmenopausal women from Australia. Ann Hum Biol. 1993, 20 (1), 47-65.

40. Van Pelt R.E., Evans E.M., Schechtman A.A., Ehsani A.A., Kohrt W.W.: Waist circumference vs body mass index for prediction of disease risk in postmenopausal women. Int J Obes Relat Metab Disord. 2001, 25 (8), 1183-1188.

41. Eaton A.W., Israel R.G., O'Brien K.F., Hortobagyi T., McCammon M.R.: Comparison of four methods to assess body composition in women. Eur J Clin Nutr. 1993, 47 (5), 353-360.

42. Lukawski H.C.: Methods for the assessment of human body composition: traditional and new. Am J Clin Nutr. 1987, 46 (4), 537-556.

43. Baranowska B., Wolińska-Witort E., Baranowska-Bik A., Bik W., Chmielowska M., Martyńska L.: Ocena układu endokrynnego polskich kobiet stuletnich. In: Skazani na długowieczność. W poszukiwaniu czynników pomyślnego starzenia. Eds: M. Mosskowska, K. Broczek, M. Witt. Ośrodek Wydawnictw Naukowych, Poznań 2007, 73-79.

\section{ANEKS}

\section{Spotkanie ze stulatką w 2007 roku}

Pani Maria urodziła się w 1902 r. jako najmłodsza z dziesięciorga rodzeństwa w podopolskich Komprachcicach. Wyszła za mąż za Jana, chłopaka z sąsiedztwa, w maju 1927 r. Szybko wybudowali własny dom, dochowali się czwórki dzieci, które mieszkają w tej samej miejscowości. Ponad pół wieku żyli w zgodzie i szczęściu - Jan zmarł 27 lat temu. Pani Maria dochowała się 12 wnucząt, 18 prawnucząt i 2 praprawnucząt.

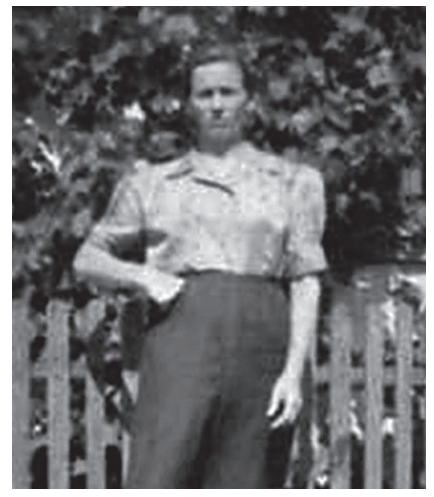

Pani Maria z czasów młodości

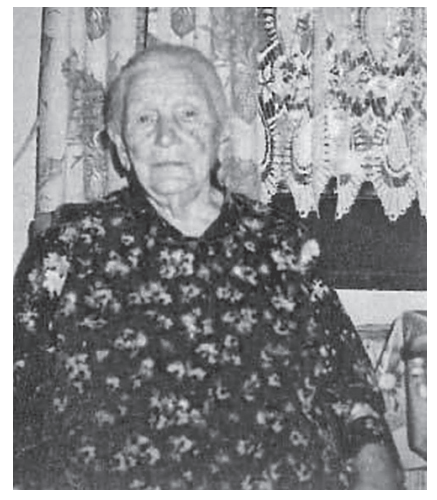

Pani Maria w wieku 105 lat
- Mieszkam z rodzinq córki Hildegardy, ale co tydzień chodzę na obiad do każdego z dzieci kolejno - mówi Pani Maria. - Co jem? Wszystko, byle nie za tłusto - dodaje.

Pani Maria ma doskonałą pamięć i cieszy się dobrym zdrowiem. Codziennie spaceruje po ogrodzie, podpierając się laseczką.

- Przed wojnq było biednie. Teraz jest wszystko - tłumaczy. - Myśmy chowali przy domu kozę, świnię, kury, żeby były najpotrzebniejsze produkty. Kiedyś wszystko było inne. Inne były „zolyty” i małżeństwa - dodaje pani Maria. - Chłopak musiał się długo starać. Dzięki temu małżeństwa długo trwały. Teraz wszystko jest robione szybko: po kilku miesiqcach młodzi się pobierają, a potem muszą się rozstać.

Nie ma recepty na długowieczność. Trzeba po prostu cieszyć się życiem - mówi. 